\title{
CHANGES OF HEAVY METAL CONTENT IN SEDIMENTS AT HAIZHOU BAY AND RISK ASSESSMENT
}

\author{
ZHANG, Y. M. ${ }^{1}$ - WANG, J. ${ }^{2 *}$ MENG, K. ${ }^{3}-$ QIU, Y. F. $^{2}$ \\ ${ }^{1}$ School of Environment, Nanjing Normal University, Nanjing 210023, China \\ ${ }^{2}$ College of Marine Science and Engineering, Nanjing Normal University, Nanjing 210023, China \\ ${ }^{3}$ Jiangsu Yunfan Testing Technology Co., Ltd., Nanjing 210023, China \\ *Corresponding author \\ e-mail: wangjing0108@njnu.edu.cn \\ (Received $15^{\text {th }}$ Apr 2019; accepted $2^{\text {nd }}$ Jul 2019)
}

\begin{abstract}
This research studied the six heavy metal contents, their distribution and the level of pollution in sediments at Haizhou Bay in 2009 and 2014. It was found that the content of cadmium $(\mathrm{Cd})$, lead $(\mathrm{Pb})$, zinc $(\mathrm{Zn})$ and copper $(\mathrm{Cu})$ accounted for the major factors in the sediments at Haizhou Bay. The content of major pollutants presented a declining trend from south to north, and the $\mathrm{Pb}$-intensive area moved from the southern waters of the study area in 2009 to the northern waters of Ganyu Port in 2014. Analysis of the pollution load index shows that the study area suffers from medium-level pollution; the most polluted area was the waters around the estuary of Dragon-King River in 2009 and Ganyu Port in 2014, which meant that development of the port had significant impact on the heavy metal contents. Assessment based on the geo-accumulation index shows that $\mathrm{Pb}$ pollution deteriorated and $\mathrm{Cd}$ pollution abated slightly over the past 5 years. Analysis of comprehensive potential risk index indicates that the ecological risk of the study area from 2009 to 2014 was at the low-medium level, with Cd being the major contributor to the risks.
\end{abstract}

Keywords: pollution assessment, spatial distribution, variation characteristics, potential ecological risk

\section{Introduction}

A bay is a recessed area where the ocean stretches into a continent, and as an area that connects a continent with the sea, it provides a space where life and production thrive and where sediments and pollutants from rivers converge (Wang et al., 2008; Reddy et al., 2016). Heavy metal contents are toxic, durable, bio-accumulative, contributive to ecological risks and hard to decompose (Nguyen et al., 2016; Harikrishnan et al., 2017; Jahan and Strezov, 2018; Zhao et al., 2018). Due to these features, heavy metal pollution is a growing concern throughout the world, posing threats to marine ecology and human health (Rahman and Ishiga, 2012; Phillips et al., 2015; Keshavarzi et al., 2018; Wang et al., 2018). In these years, many bays across the world have suffered disproportional heavy metal pollution (Hyun et al., 2007; Qiao et al., 2013; Zhang et al., 2017; Pejman et al., 2017; Celishernandez et al., 2017; Naifar et al., 2018; Qu et al., 2018; Liang et al., 2018). Heavy metals, after finding their way into the water, adhere to and accumulate in suspended sediments before being released into the water again through complicated desorption mechanisms, so marine sediments are the "confluence" and "source" of heavy metal contents (Singh et al., 2005; Guan et al., 2016). Therefore, it is of great significance to record the heavy metal contents in sediments as an environmental indicator.

Located in the northern waters of Lianyungang in Jiangsu province of China, Haizhou Bay is the only bay-styled waters in Jiangsu and is renowned as one of the 
eight largest fishing ports in China for its rich marine resources. As development of coastal regions in Jiangsu was upgraded into a national project in 2009, industrial activities along the coastline boomed and port development projects in the northern waters witnessed a rise. Previous studies on Haizhou Bay have probed into topics like the content, spatial distribution and pollution of heavy metal contents. Li and $\mathrm{Xu}$ (2014) researched the distribution and pollution of heavy metal contents in surface sediments; Zhang et al. (2013) researched on pollution of heavy metal contents in intertidal column sediments. At the year end of 2012, Ganyu Port in northern Haizhou Bay was put into operation, which inevitably led to ecological impacts on this area (Dobaradaran et al., 2018; Jahan and Strezov, 2018), but research in the influence of the port on Haizhou Bay is absent. In this study, the heavy metal pollution levels were assessed in surface sediments of Haizhou Bay in 2009 and 2014. The study objectives were to: (1) analyze the content and spatial distribution characteristics of six heavy metal contents in surface sediments in 2009 and 2014 and determine the main pollution factors of Haizhou Bay sediments; (2) Assess the content and distribution of heavy metal contents in sediments over the past five years and analyze the causes; (3) assess the extent of the contamination and ecological risks of the six heavy metal contents in sediments. This study analyzed the changes of sediments in the study area and the influence of human activities on sediments to provide data support and a scientific basis for ecological protection in Haizhou Bay.

\section{Materials and methods}

\section{Introduction to the study area}

Located in the northeast of Lianyungang city in Jiangsu province, China, Haizhou Bay is a half-open bay that adjoins East-West Tied-island of Lianyungang city on the north and reaches Mount Lan in Shandong province northwards. The seabed slopes to the east and presents a landform of "scouring in the north and silting in the south". Sediments in this area are diverse, with grits being the main sediment in the northern part, silt in the central part and clay in the southern part (Zhang and Feng, 2009; Liu et al., 2010), so the size of sediment particles increases from south to north. On the west of Haizhou Bay are estuaries of over ten rivers including Xiuzhen River and Dragon-King River which bring pollutants from the continent to the bay. Haizhou is a traditional fishing port which, as the port-based industries took off and the Ganyu Port area was put into operation in 2012, has risen to the focus in Jiangsu's initiative to extend the port and boost port-based economy.

\section{Sampling and sample processing}

On-site sampling was done in December 2009 and October 2014, and 10 samples of surface sediments were collected each time. The sampling sites are shown in Figure 1. The research targets are six types of heavy metal contents $-\mathrm{Cd}, \mathrm{As}, \mathrm{Cu}, \mathrm{Pb}, \mathrm{Cr}$ and $\mathrm{Zn}$. Sampling and analysis performed in October 2014 were in accordance with technical standards specified in "The Specification for Marine Monitoring - Part 5: Sediment Analysis" (GB17378.5-2007). Using the grab sampler, we collected 3 to 4 sample surface sediments with a grain diameter within $5 \mathrm{~cm}$ and placed the samples into widemouthed reagent bottles and polyethylene bags for frozen storage. During analysis of the samples, we made use of atomic absorption spectrometry (AAS) to detect $\mathrm{Cu}, \mathrm{Pb}$, 
$\mathrm{Zn}, \mathrm{Cr}$ and $\mathrm{Cd}$, and used atomic absorption spectrometry to detect As. All reagents used for analysis of heavy metal contents were guaranteed reagents and water used in experiments was ultrapure water. Meanwhile, parallel samples were used to realize quality control and the testing errors between parallel samples of these six heavy metal contents were all below 5\%. The heavy metal content detection method performed is detailed in the reference by $\mathrm{Li}$ and $\mathrm{Xu}$ (2014).

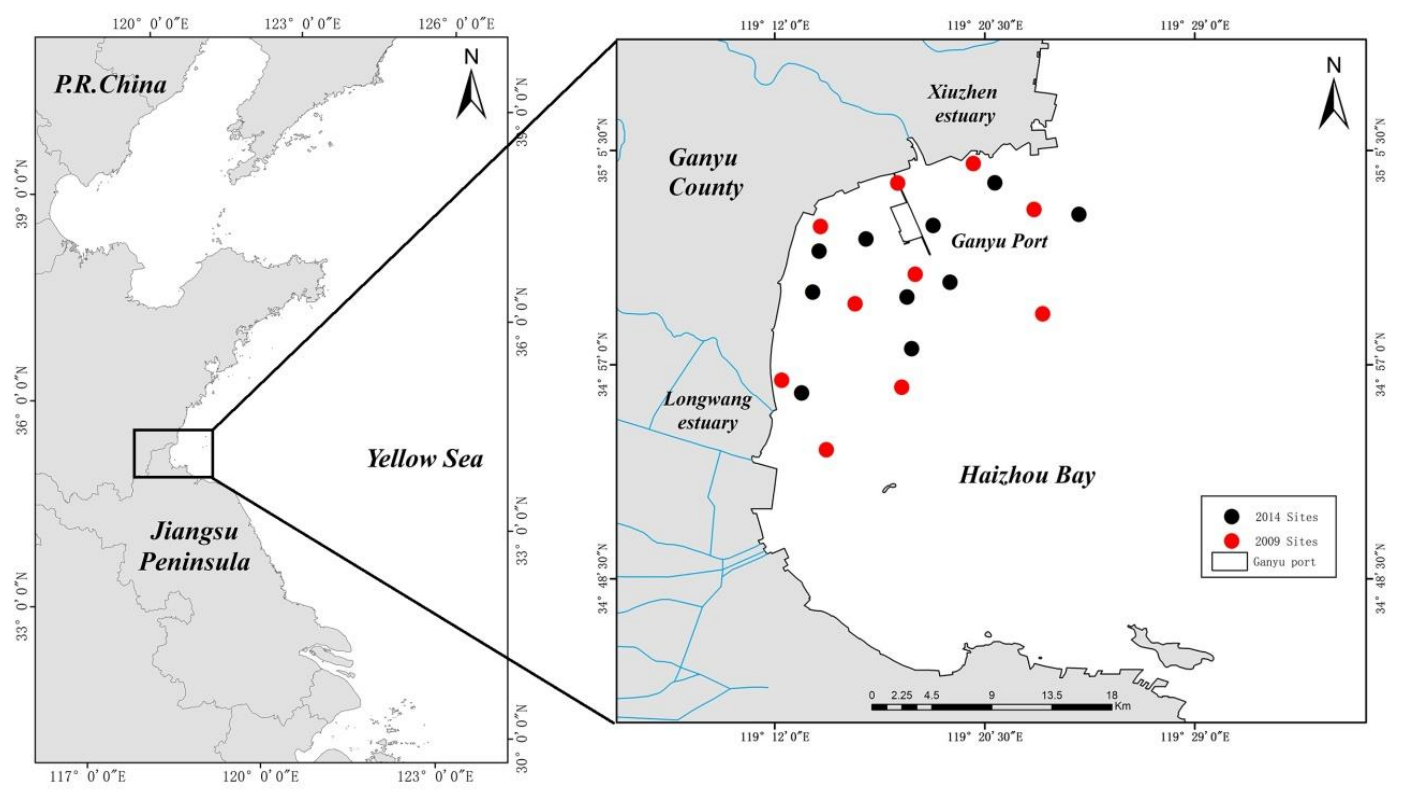

Figure 1. Location of sample sites

\section{Methods}

\section{Pollution load index (PLI)}

The pollution load index was first proposed by Tomlinson in 1980 to assess pollution by different chemical elements at different sites. The equations for calculation are:

$$
\begin{gathered}
P L I=\sqrt[n]{C_{f}^{1} \times C_{f}^{2} \times C_{f}^{3} \times \ldots \times C_{f}^{\mathrm{n}}} \\
C_{f}^{i}=C_{\mathrm{n}}^{i} / C_{0}^{i}
\end{gathered}
$$

where PLI refers to the pollution load index of a certain site, $C_{f}^{i}$ the pollution index of one element, $C_{\mathrm{n}}^{i}$ the value obtained through actual measurement, and $C_{0}^{i}$ the background value. The grading standard for PLI (Tomlinson et al., 1980; Zhu et al., 2013) is shown in Table 1.

\section{Geo-accumulation index}

Geo-accumulation Index (Igeo) was first proposed by G. Müller, a German scientist. It is a quantitative index for assessment of heavy metal contents in sediments and can be used to assess pollution caused by heavy metal contents. The calculation equation is: 


$$
I_{\text {geo }}=\log _{2} \frac{C_{n}}{1.5 B_{n}}
$$

where $\mathrm{Cn}$ denotes the content of Element $\mathrm{n}$ in actual measurement, and $\mathrm{Bn}$ is the background value of this element on earth which, in this research, specifically refers to the background value of the content of the researched element in the tidal marsh of Jiangsu province measured in the 1980 s by Chen et al. (1985). 1.5 is a coefficient identified by considering possible changes caused by differences of rocks in different places. The grading standard of geo-accumulation index (Müller, 1969) is also shown in Table 1 .

\section{Potential ecological risk index}

The potential ecological risk index was first proposed by a Swedish environmentalist named Hakanson in 1980 to assess the potential ecological hazards of heavy metal contents in sediments. This method combines the ecological impact, environmental impact and toxicologic research of heavy metal contents to reflect the potential ecological risks of heavy metals. The calculation equations are:

$$
\begin{gathered}
C_{f}^{i}=C_{\mathrm{n}}^{i} / C_{0}^{i} \\
E_{r}^{i}=T_{r}^{t} \times C_{f}^{i} \\
R I=\sum\left(E_{\mathrm{r}}^{i}\right)
\end{gathered}
$$

where $R I$ is the value of comprehensive potential ecological risks, $E_{r}^{i}$ the value of potential risks of one element. $T_{r}^{t}$ denotes the toxicological coefficient of an element which, in this research, adopts the standard toxicological coefficients of heavy metal contents proposed by Hakanson (1980): the respective toxicological coefficients of $\mathrm{Cd}$, $\mathrm{As}, \mathrm{Cu}, \mathrm{Pb}, \mathrm{Cr}$ and $\mathrm{Zn}$ are $30,10,5,5,2$, and $1 . C_{f}^{i}$ is the pollution coefficient of a certain element, $C_{n}{ }^{i}$ the value obtained through actual measurement and $C_{0}{ }^{i}$ the background value. The grading standard for the potential ecological risk index of a given element and for the comprehensive potential ecological risk index is also presented in Table 1.

\section{Results and discussion}

\section{Changes in the heavy metal contents}

The heavy metal contents in surface sediments in the study area detected in 2009 and 2014 are shown in Table 2. The ranges of the heavy metal contents $(\mathrm{mg} / \mathrm{kg})$ at different sampling sites in 2009 were: 3.89-8.26 for As (averaged at 5.42), 10.9-29.5 for $\mathrm{Cu}$ (averaged at 17.85), 11.8-19.7 for $\mathrm{Pb}$ (averaged at 15.875), 37.4-98.8 for $\mathrm{Zn}$ (average at 61.96), 38.6-94.9 for $\mathrm{Cr}$ (averaged at 63.1) and 0.0964-0.247 for $\mathrm{Cd}$ (averaged at $0.144)$. The ranges of the heavy metal contents $(\mathrm{mg} / \mathrm{kg})$ at different sampling sites measured in 2014 were: 6.32-11.31 for As (averaged at 9.16), 11.89-30.69 for $\mathrm{Cu}$ (averaged at 20.97), 21.40-43.28 for $\mathrm{Pb}$ (averaged at 31.59), 15.6-118.70 for $\mathrm{Zn}$ 
(averaged at 81.29), 24.74-77.01 for $\mathrm{Cr}$ (averaged at 47.38), 0.07-0.15 for Cd (averaged at 0.11 ). Compared with the data in 2009 , the average content of $\mathrm{Pb}, \mathrm{As}, \mathrm{Zn}$ and $\mathrm{Cu}$ increased by $98.68 \%, 68.85 \%$ and $17.48 \%$ in 2014 , while the average content of $\mathrm{Cd}$ and $\mathrm{Cr}$ declined by $23.83 \%$ and $24.90 \%$, respectively. In comparison with the heavy metal contents in sediments obtained by studies in China and other countries (see Table 2), the content of $\mathrm{Cu}, \mathrm{Cd}$ and $\mathrm{Pb}$ in sediments in Haizhou Bay exceeded that in other regions, and the content of $\mathrm{Zn}$ and $\mathrm{Cr}$ stayed at a medium level.

Table 1. Grading standard for geo-accumulation index and potential ecological risk index of heavy metal contents

\begin{tabular}{|c|c|c|c|c|c|c|c|}
\hline$I_{g e o}$ & Pollution Level & $P L I$ & Pollution level & $\boldsymbol{E}_{r}^{i}$ & $\begin{array}{c}\text { Single-factor } \\
\text { potential } \\
\text { ecological risk }\end{array}$ & $R I$ & $\begin{array}{c}\text { Comprehensive } \\
\text { potential } \\
\text { ecological risk }\end{array}$ \\
\hline$\leq 0$ & No pollution & $<1$ & No pollution & $<40$ & Low & $<110$ & Low \\
\hline $0 \sim 1$ & Mild pollution & $1 \sim 2$ & $\begin{array}{l}\text { Medium } \\
\text { pollution }\end{array}$ & $40 \sim 80$ & Medium & $110 \sim 220$ & Medium \\
\hline $1 \sim 2$ & $\begin{array}{l}\text { Mild-medium } \\
\text { pollution }\end{array}$ & $2 \sim 3$ & $\begin{array}{c}\text { Heavy } \\
\text { pollution }\end{array}$ & $80 \sim 160$ & Medium-high & $220 \sim 440$ & High \\
\hline $2 \sim 3$ & $\begin{array}{l}\text { Medium } \\
\text { pollution }\end{array}$ & $\geq 3$ & $\begin{array}{c}\text { Severe } \\
\text { pollution }\end{array}$ & $160 \sim 320$ & High & $\geq 440$ & Extremely high \\
\hline $3 \sim 4$ & $\begin{array}{l}\text { Serious } \\
\text { pollution }\end{array}$ & & & $\geq 320$ & Extremely high & & \\
\hline $4 \sim 5$ & Heavy pollution & & & & & & \\
\hline$>5$ & $\begin{array}{c}\text { Severe } \\
\text { pollution }\end{array}$ & & & & & & \\
\hline
\end{tabular}

Table 2. Comparison of heavy metal contents in the study area $(\mathrm{mg} / \mathrm{kg})$

\begin{tabular}{|c|c|c|c|c|c|c|c|c|}
\hline \multicolumn{2}{|c|}{ Project (sampling time) } & As & $\mathbf{C u}$ & $\mathbf{P b}$ & $\mathbf{Z n}$ & $\mathrm{Cr}$ & Cd & Source \\
\hline Hanzhou & Maximum & 8.26 & 29.5 & 19.7 & 98.8 & 94.9 & 0.247 & \multirow{6}{*}{ This study } \\
\hline Bay, China & Minimum & 3.89 & 10.9 & 11.8 & 37.4 & 38.6 & 0.0964 & \\
\hline (2009.12) & Mean & 5.42 & 17.85 & 15.875 & 61.96 & 63.1 & 0.144 & \\
\hline Haizhou & Maximum & 11.31 & 30.69 & 43.28 & 118.70 & 77.01 & 0.15 & \\
\hline Bay, China & Minimum & 6.32 & 11.89 & 21.40 & 15.60 & 24.74 & 0.07 & \\
\hline$(2014.10)$ & Mean & 9.16 & 20.97 & 31.59 & 81.29 & 47.38 & 0.11 & \\
\hline \multicolumn{2}{|c|}{$\begin{array}{l}\text { Soil background value of tidal } \\
\text { marsh in Jiangsu province }\end{array}$} & 7.38 & 15.02 & 11.40 & 47.15 & 60.11 & 0.042 & $\begin{array}{c}\text { Chen et al. } \\
\text { (1985) }\end{array}$ \\
\hline \multicolumn{2}{|c|}{ Jiaozhou Bay, China } & n.d. & 38.8 & 55.2 & 107.4 & 69.9 & 0.42 & $\begin{array}{l}\text { Liang et al. } \\
\text { (2018) }\end{array}$ \\
\hline \multicolumn{2}{|c|}{ Laizhou Bay, China } & 4.84 & 6.89 & 14.01 & n.d. & 17.10 & 0.08 & $\begin{array}{l}\text { Zhang et al. } \\
\text { (2017) }\end{array}$ \\
\hline \multicolumn{2}{|c|}{ San Francisco Bay, USA } & n.d. & 38.6 & 21.8 & 153.2 & 21.1 & 0.2 & $\begin{array}{l}\text { Lu et al. } \\
\text { (2005) }\end{array}$ \\
\hline \multicolumn{2}{|c|}{ Persian Gulf, Iran } & n.d. & 32.1 & 48.3 & 62.5 & 89 & 0.8 & $\begin{array}{l}\text { Pejman et al. } \\
\text { (2017) }\end{array}$ \\
\hline \multicolumn{2}{|c|}{ Gabes Gulf, Tunisia } & 4.17 & 37 & 10.71 & 104.90 & 77.22 & 8.14 & $\begin{array}{l}\text { Naifar et al., } \\
\quad 2018\end{array}$ \\
\hline \multicolumn{2}{|c|}{ Masan Bay, Korea } & n.d. & 43.4 & 44 & 206 & 67.1 & 1.24 & $\begin{array}{l}\text { Hyun et al. } \\
\text { (2007) }\end{array}$ \\
\hline
\end{tabular}

n.d.: not detected 
In 2009, the average content of five heavy metals $-\mathrm{Cd}, \mathrm{Pb}, \mathrm{Zn}, \mathrm{Cu}$ and $\mathrm{Cr}$, exceeded the background value of the heavy-metal content in the tidal marsh of Jiangsu province, the detected values of these five heavy metals being 3.42 times, 1.39 times, 1.31 times, 1.19 times and 1.05 times as much as the background values, so $\mathrm{Cd}, \mathrm{Pb}, \mathrm{Zn}$ and $\mathrm{Cu}$ are the main factors that exceeded the background value. In 2014, the average content of five heavy metals - $\mathrm{Pb}, \mathrm{Cd}, \mathrm{Zn}, \mathrm{Cu}$ and $\mathrm{As}$, exceeded the background value of heavymetal content in the tidal marsh of Jiangsu province, with the detected values of these five metals being 2.77 times, 2.51 times, 1.72 times, 1.40 times and 1.24 times as much as the background values, so the main factors that exceeded the average value are $\mathrm{Cd}$, $\mathrm{Pb}, \mathrm{Zn}$ and $\mathrm{Cu}$. The degree to which the content of $\mathrm{Pb}, \mathrm{Zn}$ and $\mathrm{Cu}$ exceeded the background value increased, among which the most salient was that of $\mathrm{Pb}$; though the degree to which the content of $\mathrm{Cd}$ exceeded the background value declined, its degree of enrichment remains salient.

\section{Spatial distribution of major factors of high-level content}

In light of results of research done in 2009 and 2014 (locations of research sites are shown in Fig. 1), we concluded the distribution of major factors of high-level content $(\mathrm{Cd}, \mathrm{Pb}, \mathrm{Zn}$ and $\mathrm{Cu})$ in Figure 2.
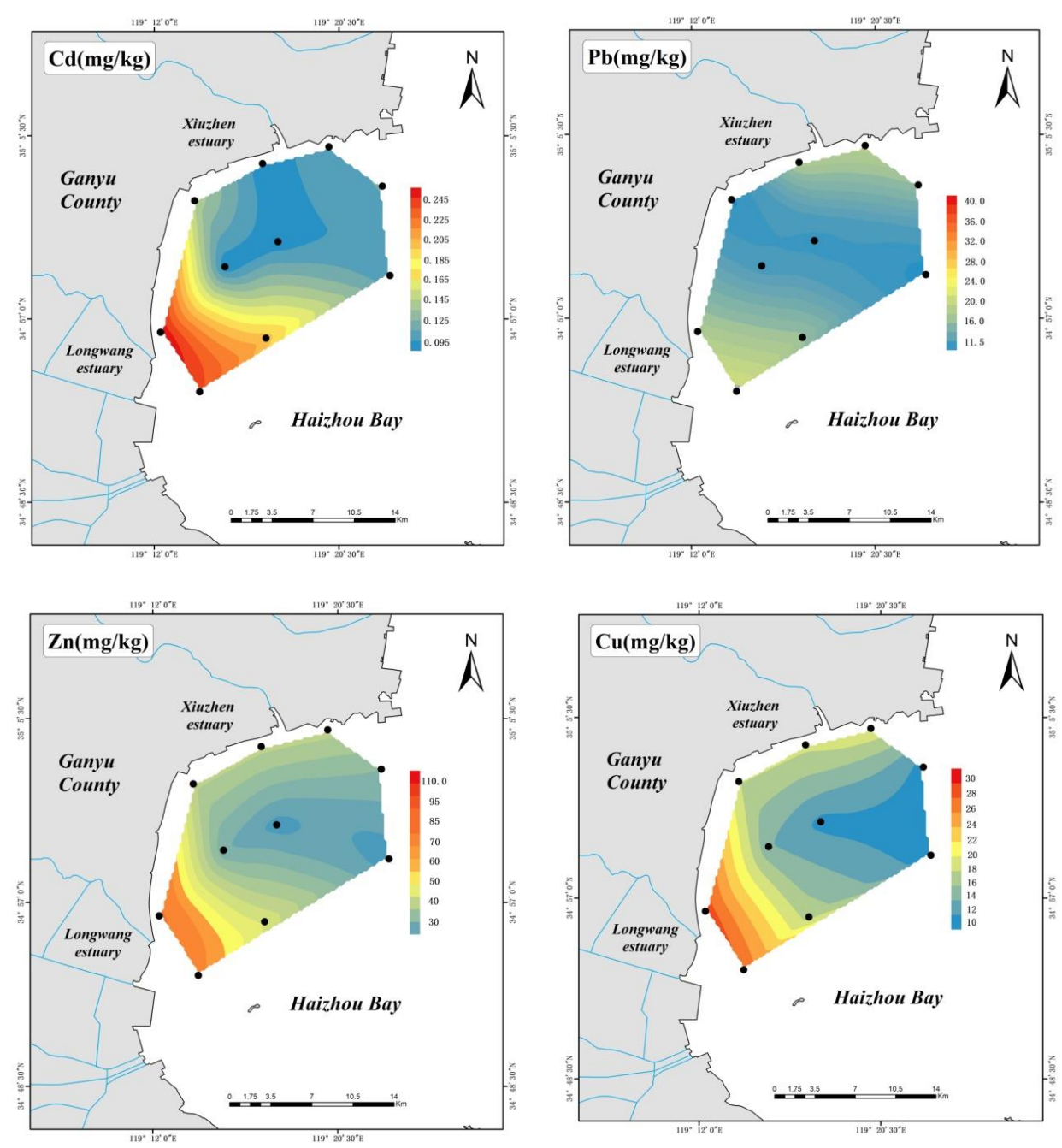

Figure 2. a Spatial distribution of heavy metal contents in 2009 

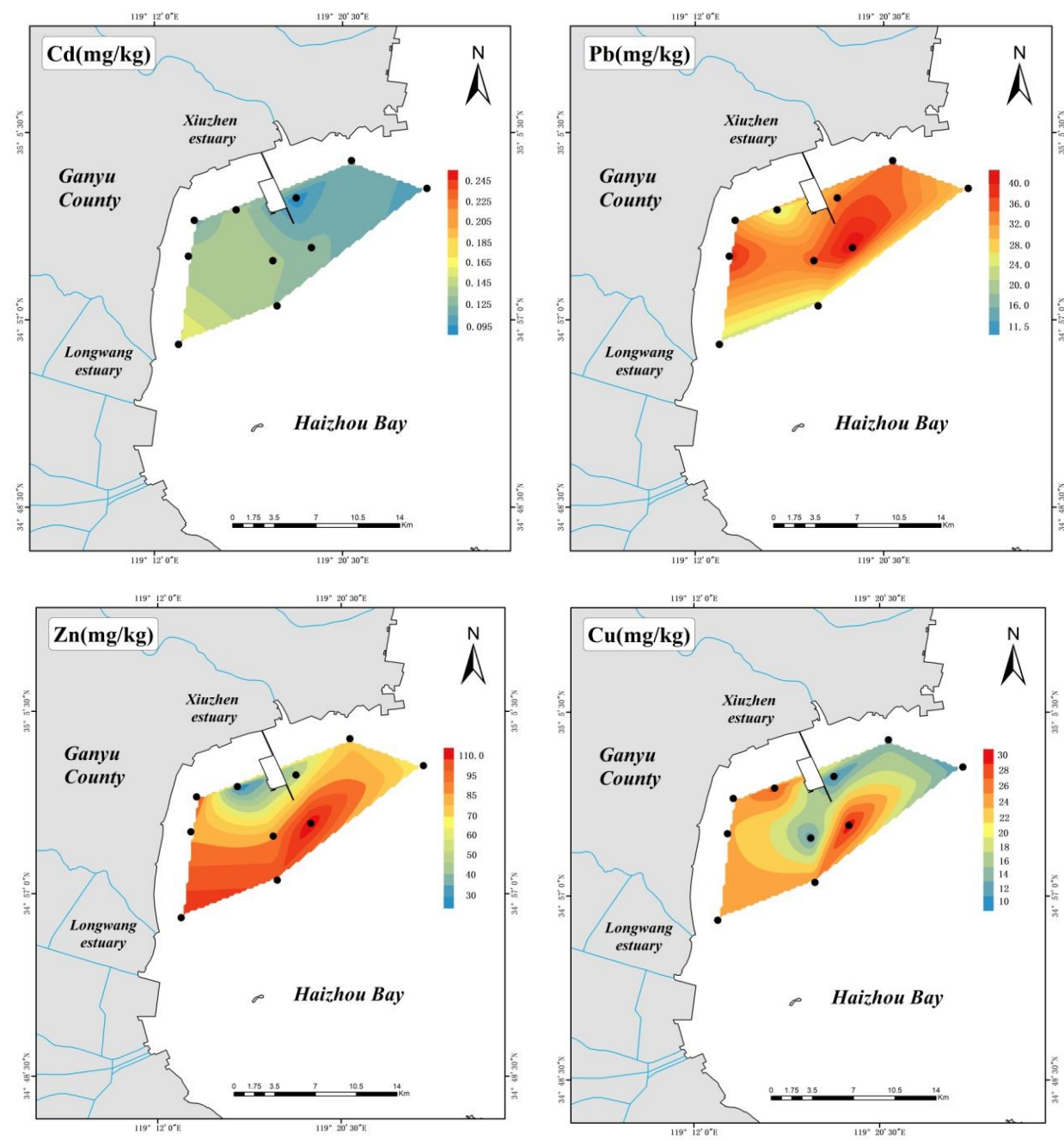

Figure 2. b Spatial distribution of heavy metal contents in 2014

In 2009, the content of these four heavy metal contents declined from south to north, and the distribution of $\mathrm{Cd}, \mathrm{Zn}$ and $\mathrm{Cu}$ nearly followed the same pattern as in 2009. Like the heavy metal contents, the size of sediment particles also followed a declining trend from south to north. As proved by many previous studies, the heavy metal contents and the size of sediment particles are interrelated (Li et al., 2015): the larger the surface area of a sediment particle, the more heavy metals it absorbs, and the larger the grain size, the lower the level of enrichment of heavy metals. However, the Pb-intensive area moved from the southern waters in 2009 to the waters around Ganyu Port in 2014, which indicated that the increase of pollutants from ships due to development of Ganyu Port led to a rise of the heavy metal contents.

\section{Characteristics of heavy-metal pollution}

Table 3 shows the pollution load index (Eqs. 1 and 2) of heavy metal contents in surface sediments in the study area, and Figure 3 demonstrates the distribution of the pollution load index in sampling sites. In 2009, the pollution load index at the sampling sites changes between 0.92 to 1.96 , and the pollution level varies from no pollution to medium pollution. Among all the sampling sites, $80 \%$ are rated as medium pollution 
and $20 \%$ rated as no pollution. In 2014 , the pollution load index at the sampling sites changes between 1.12 and 2.12 , and the degree of pollution varies from medium pollution to severe pollution; $10 \%$ of the sampling sites suffer from severe pollution and $90 \%$ from medium pollution. Thus, the pollution load index in 2014 is higher than that in 2009. From the map for distribution of pollution load index, the waters around the estuary of Dragon-King River had the highest pollution load index in 2009, while in 2014, both the estuary of Dragon-King River and the waters around Ganyu Port had a high pollution load index, making Ganyu Port another area of severe pollution. It indicates that development of the bay has led to tangible impacts on the sediments and hence deserves more attention.
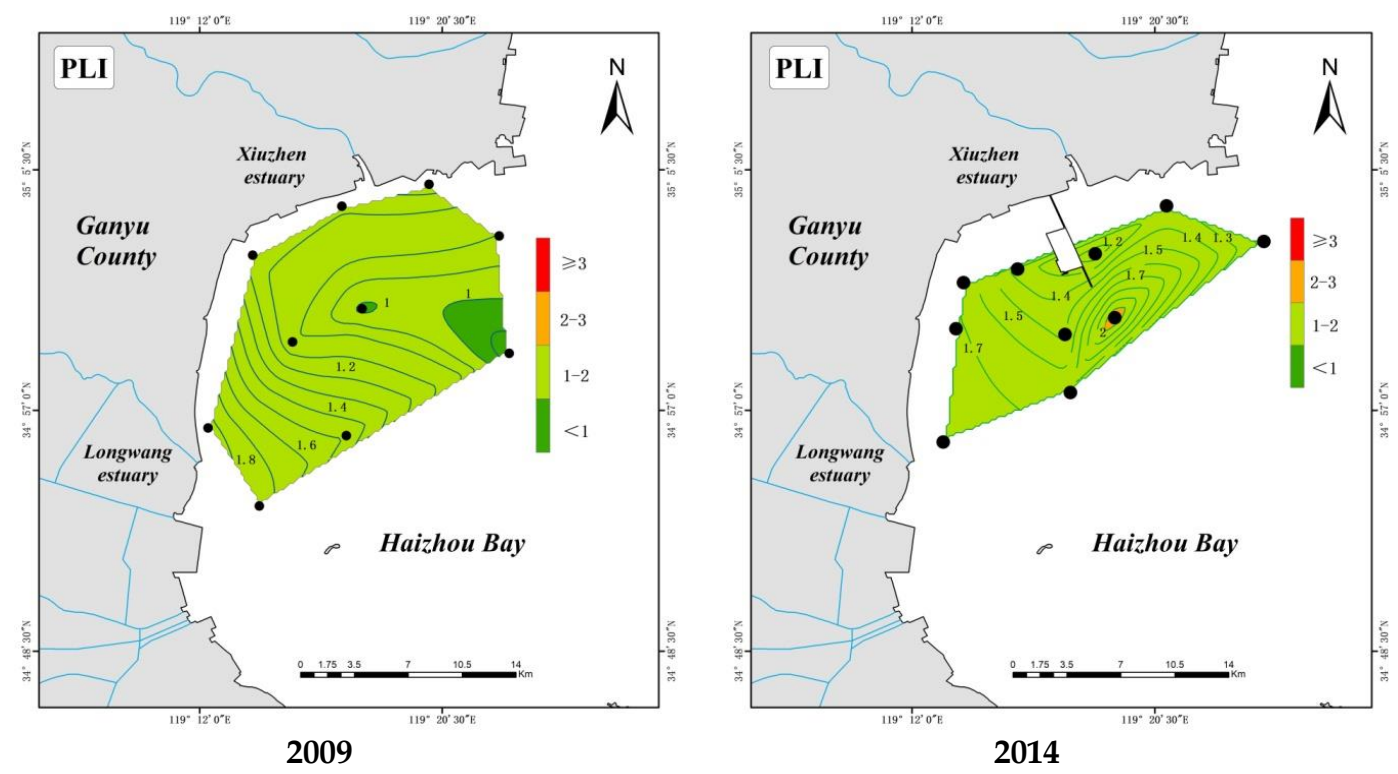

Figure 3. The distribution of the pollution load index of heavy metals in surface sediments

Table 3. Pollution load index and pollution degree of heavy metals in surface sediments of the study area

\begin{tabular}{c|c|c|c|c|c}
\hline \multicolumn{3}{l}{ 2009.12 } & \multicolumn{3}{c}{ 2014.10 } \\
\hline Sampling site & PLI & Pollution degree & Sampling site & PLI & Pollution degree \\
\hline 1 & 1.85 & Medium pollution & 1 & 1.34 & Medium pollution \\
2 & 1.96 & Medium pollution & 2 & 1.17 & Medium pollution \\
3 & 1.59 & Medium pollution & 3 & 1.12 & Medium pollution \\
4 & 1.11 & Medium pollution & 4 & 1.35 & Medium pollution \\
5 & 1.24 & Medium pollution & 5 & 2.12 & Severe pollution \\
6 & 0.99 & No pollution & 6 & 1.69 & Medium pollution \\
7 & 0.92 & No pollution & 7 & 1.47 & Medium pollution \\
8 & 1.21 & Medium pollution & 8 & 1.72 & Medium pollution \\
9 & 1.28 & Medium pollution & 9 & 1.66 & Medium pollution \\
10 & 1.10 & Medium pollution & 10 & 1.77 & Medium pollution \\
Minimum & 0.92 & & Minimum & 1.12 & \\
Maximum & 1.96 & & Maximum & 2.12 & \\
Mean & 1.34 & Medium pollution & Mean & 1.54 & Medium pollution \\
\hline
\end{tabular}


Table 4 demonstrates assessment of the geo-accumulation index (Eq. 3). In 2009, the mean of the geo-accumulation index of the six heavy metals in surface sediments in Haizhou Bay is sequenced as $\mathrm{Cd}>\mathrm{Pb}>\mathrm{Zn}>\mathrm{Cu}>\mathrm{Cr}>\mathrm{As}$, among which $\mathrm{Cd}$ shows the highest level of enrichment and is rated as mild-medium pollution in terms of the level of pollution, As is rated as no pollution and the other four metals are rated as clean or mild pollution. In 2014, the mean of geo-accumulation index of the six heavy metal contents in surface sediments in Haizhou Bay is sequenced as $\mathrm{Pb}>\mathrm{Cd}>\mathrm{Zn}>\mathrm{Cu}>\mathrm{As}>\mathrm{Cr}$, among which $\mathrm{Pb}$ has the highest geo-accumulation index and is rated as severe pollution, followed by $\mathrm{Cd}$, and the other four metals are rated as clean or no pollution in terms of the level of pollution. It can be concluded that from 2009 to 2014, the pollution of $\mathrm{Pb}$ witnessed a tangible increase while the pollution of $\mathrm{Cd}$ has been mitigated. In light of the spatial distribution of $\mathrm{Pb}$ in 2014, it can be seen that $\mathrm{Pb}$ accumulates in waters around Ganyu Port and its accumulation is closely linked to the number of ships. Relevant studies have proved that consumption of leaded gasoline would increase the content of $\mathrm{Pb}$ in the environment (Blake and Goulding, 2002; Wilcke et al., 1998; Lv et al., 2015). The Ganyu Port is teeming with ships and burning of leaded gasoline increases the risks of $\mathrm{Pb}$ pollution. $\mathrm{Cd}$ is a standard element in fertilizers ( $\mathrm{Lv}$ et al., 2015). The mitigation of $\mathrm{Cd}$ pollution may be attributed to promotion of advanced agricultural technologies, strengthened control over fertilizers and other ecological protection measures.

Table 4. Geo-accumulation index and potential ecological risk index of heavy metals in surface sediments of the study area

\begin{tabular}{|c|c|c|c|c|c|c|c|c|}
\hline \multicolumn{3}{|c|}{ Project (sampling time) } & As & $\mathbf{C u}$ & $\mathbf{P b}$ & $\mathbf{Z n}$ & $\mathrm{Cr}$ & Cd \\
\hline \multirow{4}{*}{$I_{g e o}$} & \multirow{2}{*}{2009.12} & Range (mean) & $\begin{array}{c}-1.51 \sim-0.42 \\
(-1.07)\end{array}$ & $\begin{array}{c}-1.05 \sim 0.39 \\
(-0.42) \\
\end{array}$ & $\begin{array}{c}-0.54 \sim 0.2 \\
(-0.13) \\
\end{array}$ & $\begin{array}{c}-0.92 \sim 0.48 \\
(-0.26)\end{array}$ & $\begin{array}{c}-1.22 \sim 0.07 \\
(-0.57) \\
\end{array}$ & $\begin{array}{c}0.61 \sim 1.97 \\
(1.10) \\
\end{array}$ \\
\hline & & $\begin{array}{l}\text { Degree of } \\
\text { pollution }\end{array}$ & Clean & $\begin{array}{c}\text { Clean } \sim \text { mild } \\
\text { pollution }\end{array}$ & $\begin{array}{l}\text { Clean } \sim \text { mild } \\
\text { pollution }\end{array}$ & $\begin{array}{l}\text { Clean } \sim \text { mild } \\
\text { pollution }\end{array}$ & $\begin{array}{l}\text { Clean } \sim \text { mild } \\
\text { pollution }\end{array}$ & $\begin{array}{c}\text { Mild } \sim \text { mild- } \\
\text { medium pollution }\end{array}$ \\
\hline & \multirow{2}{*}{2014.10} & Range (mean) & $\begin{array}{c}-0.81 \sim 0.03 \\
(-0.30)\end{array}$ & $\begin{array}{c}-0.92 \sim 0.45 \\
(-0.18)\end{array}$ & $\begin{array}{c}0.32 \sim 1.34 \\
(0.84)\end{array}$ & $\begin{array}{c}-2.18 \sim 0.75 \\
(0.03)\end{array}$ & $\begin{array}{c}-1.88 \sim-0.23 \\
(-1.03)\end{array}$ & $\begin{array}{c}0.21 \sim 1.22 \\
(0.72) \\
\end{array}$ \\
\hline & & $\begin{array}{l}\text { Degree of } \\
\text { pollution }\end{array}$ & $\begin{array}{l}\text { Clean-mild } \\
\text { pollution }\end{array}$ & $\begin{array}{c}\text { Clean-mild } \\
\text { pollution }\end{array}$ & $\begin{array}{c}\text { Mild } \sim \text { mild- } \\
\text { medium pollution }\end{array}$ & $\begin{array}{c}\text { Clean-mild } \\
\text { pollution }\end{array}$ & $\begin{array}{c}\text { Clean-mild } \\
\text { pollution }\end{array}$ & $\begin{array}{c}\text { Mild } \sim \text { mild- } \\
\text { medium pollution }\end{array}$ \\
\hline \multirow{4}{*}{$E_{r}^{i}$} & \multirow[t]{2}{*}{2009.12} & Range (mean) & $\begin{array}{l}5.27 \sim 11.19 \\
\quad(7.35)\end{array}$ & $\begin{array}{l}3.63 \sim 9.82 \\
(5.94)\end{array}$ & $\begin{array}{c}1.04 \sim 1.73 \\
(1.39)\end{array}$ & $\begin{array}{l}5.18 \sim 8.64 \\
(6.97)\end{array}$ & $\begin{array}{l}1.28 \sim 3.16 \\
(2.10)\end{array}$ & $\begin{array}{c}68.86 \sim 176.43 \\
(102.59)\end{array}$ \\
\hline & & Ecological risk & Low & Low & Low & Low & Low & Medium $\sim$ high \\
\hline & \multirow{2}{*}{2014.10} & Range (mean) & $\begin{array}{c}8.56 \sim 15.33 \\
(12.41)\end{array}$ & $\begin{array}{c}3.96 \sim 10.22 \\
(6.98)\end{array}$ & $\begin{array}{c}1.88 \sim 3.80 \\
(2.77)\end{array}$ & $\begin{array}{c}9.39 \sim 18.98 \\
(13.86)\end{array}$ & $\begin{array}{c}0.82 \sim 2.56 \\
(1.58)\end{array}$ & $\begin{array}{c}52.14 \sim 105.00 \\
(75.43)\end{array}$ \\
\hline & & Ecological risk & Low & Low & Low & Low & Low & $\begin{array}{l}\text { Medium- } \\
\text { relatively high }\end{array}$ \\
\hline \multirow{4}{*}{$R I$} & \multirow{2}{*}{2009.12} & Range (mean) & \multicolumn{6}{|c|}{ 90.33 208.14（126.35） } \\
\hline & & Ecological risk & \multicolumn{6}{|c|}{ Low $\sim$ medium } \\
\hline & \multirow{2}{*}{2014.10} & Range (mean) & \multicolumn{6}{|c|}{$83.92 \sim 141.14 \quad(113.02)$} \\
\hline & & Ecological risk & \multicolumn{6}{|c|}{ Low $\sim$ medium } \\
\hline
\end{tabular}

\section{Assessment of potential ecological risk}

According to Table 1, we achieved the potential ecological risk of each heavy metal (Eqs. 4 and 5) and the comprehensive ecological risk (Eq. 6) in 2009 and 2014, as shown in Table 4. Figure 4 shows the distribution of the comprehensive ecological risk index. In 2009, the mean of potential ecological risk of $\mathrm{As}, \mathrm{Cu}, \mathrm{Pb}, \mathrm{Zn}, \mathrm{Cr}$ and $\mathrm{Cd}$ is 7.35, 5.94, 1.39, 6.97, 2.10 and 102.59; and when these metals are sequenced according 
to the size of the mean, it is $\mathrm{Cd}>\mathrm{As}>\mathrm{Zn}>\mathrm{Cu}>\mathrm{Cr}>\mathrm{Pb}$, and the ecological risk of $\mathrm{Cd}$ is rated as medium $\sim$ high. In 2014, the mean of potential ecological risks of $\mathrm{As}, \mathrm{Cu}, \mathrm{Pb}$, $\mathrm{Zn}, \mathrm{Cr}$ and $\mathrm{Cd}$ is $12.41,6.98,2.77,13.86,1.58$ and 75.43, so the sequence changes into $\mathrm{Cd}>\mathrm{Zn}>\mathrm{As}>\mathrm{Cu}>\mathrm{Pb}>\mathrm{Cr}$, and the ecological risk of $\mathrm{Cd}$ is rated medium relatively high. From 2009 to 2014, Cd remains the main contributor to potential ecological risks in the study area.

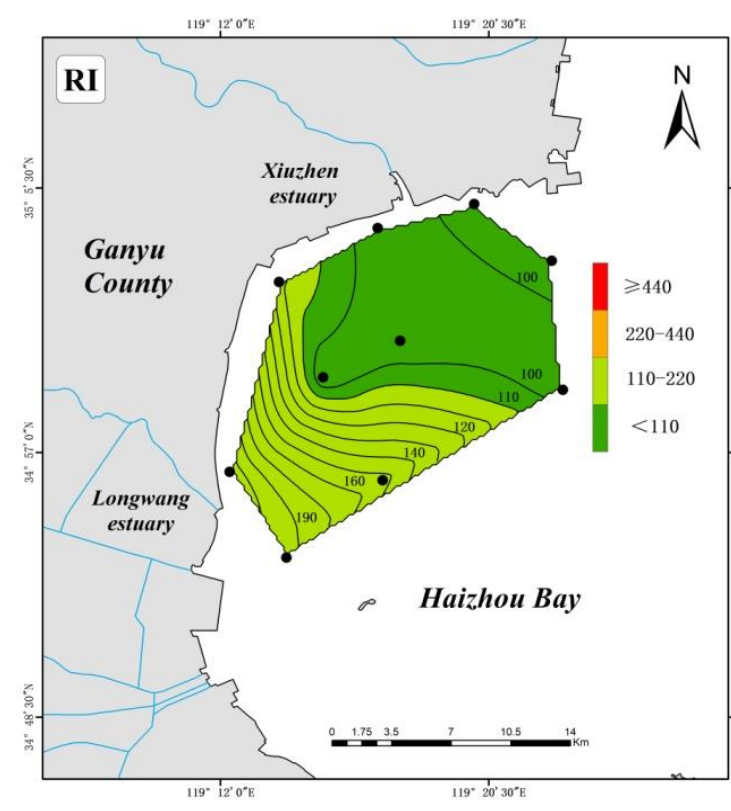

2009

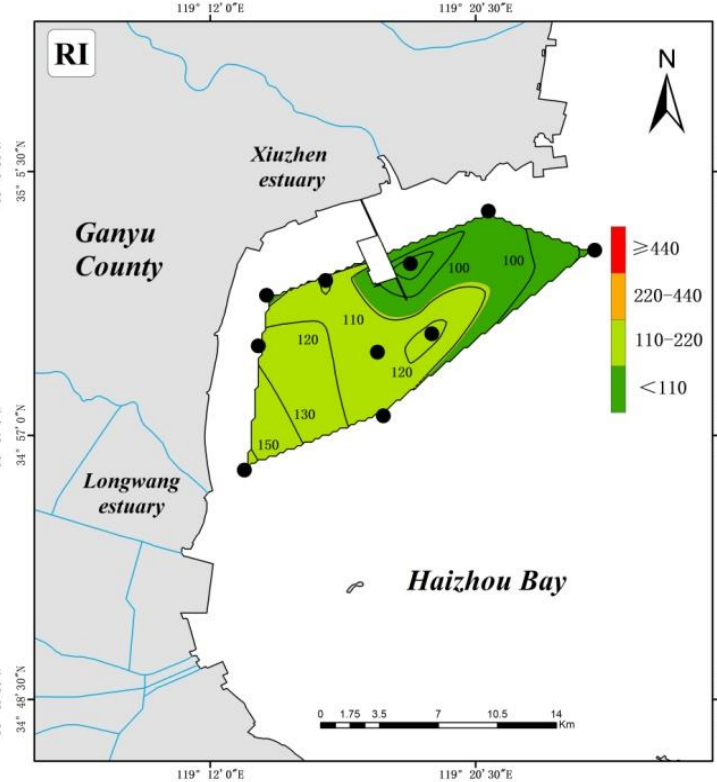

2014

Figure 4. The distribution of the comprehensive ecological risk index

In 2009, the mean of RI (comprehensive potential ecological risk index) of the study area is 126.35, which falls between 90.33 and 208.14, rated low medium in terms of the level of risks. In 2014, the mean of RI is 113.02, which falls between 89.92 and 141.14, rated low medium in terms of the level of risks. According to the map of comprehensive potential ecological risk index distribution (Fig. 4), from 2009 to 2014, the comprehensive potential ecological risk index reaches the highest level in the waters around the estuary of Dragon-King River and declines northwards, which is consistent with the spatial distribution of the main pollutant $-\mathrm{Cd}$. Therefore, the waters around the estuary of Dragon-King River remains a region most susceptible to ecological risks in the study area and hence deserves more attention.

\section{Conclusion}

As the result shows, in 2009, the average content of $\mathrm{As}, \mathrm{Cu}, \mathrm{Pb}, \mathrm{Zn}, \mathrm{Cr}$ and $\mathrm{Cd}$ is $5.42,17.85,15.875,61.96,63.1$ and 0.144 , respectively (unit: $\mathrm{mg} / \mathrm{kg}$ ), while in 2014 , the number changes to $9.13,21.45,31.99,84.80,48.85$ and 0.11 (unit: $\mathrm{mg} / \mathrm{kg}$ ). From 2009 to 2014, $\mathrm{Cd}, \mathrm{Pb}$ and $\mathrm{Zn}$ account for the main factors that push the value of heavymetal content in Haizhou Bay above the soil background value of tidal marshes in 
Jiangsu province; the content of $\mathrm{Pb}, \mathrm{Zn}$ and $\mathrm{Cu}$ rises, with $\mathrm{Pb}$ witnessing the largest increase; the content of $\mathrm{Cd}$ decreases slightly but its level of enrichment remains high.

The major pollution factors in $2009(\mathrm{Cd}, \mathrm{Pb}, \mathrm{Zn}$ and $\mathrm{Cu})$ and those in $2014(\mathrm{Cd}, \mathrm{Zn}$ and $\mathrm{Cu}$ ) present a similar trend in spatial distribution, with their content declining from south to north, but the $\mathrm{Pb}$-intensive area moved from the southern waters in 2009 to the waters around Ganyu Port in 2014.

Analysis of the geo-accumulation index shows that from 2009 to 2014, the pollution of $\mathrm{Pb}$ witnessed tangible increase while the pollution of $\mathrm{Cd}$ was mitigated. Analysis of the pollution load index shows that the study area suffers from medium-level pollution and the pollution increases from 2009 to 2014. In 2009, the estuary of Dragon-King River was the most polluted area, while in 2014, the waters around Ganyu Port accounted for another severely-polluted area, which reflects the obvious influence of port development on the heavy metal contents in sediments in the study area. The pollution of $\mathrm{Cd}$ is closely linked to the amount of pollutants brought by Dragon-King River from the continent.

Analysis of the single-factor potential ecological risk shows that the ecological risk of $\mathrm{Cd}$ is rated medium $\sim$ high, while that of other heavy metals is rated low. Assessment of the comprehensive potential ecological risk shows that the ecological risk of the study area from 2009 to 2014 is rated low medium, the waters around the estuary of Dragon-King River remains a region most susceptible to ecological risks and is hence worth more attention.

$\mathrm{Cd}, \mathrm{Pb}, \mathrm{Zn}$ and $\mathrm{Cu}$ are the main pollution factors in the sediments of the study sea area. Further attention should be paid to the changes trend of these four heavy metal contents and their influencing factors in the sediments of the study sea area in the future. Pollution from rivers and ports has affected the heavy metal contents of sediments in the study area. With the construction and development of Ganyu Port, its impact on heavy metals in sediments needs further investigation and study. In the future, we should strengthen the control of river and port discharge in the study area to reduce the impact on heavy metals in marine sediments.

\section{REFERENCES}

[1] Blake, L., Goulding, K. W. T. (2002): Effects of atmospheric deposition, soil pH and acidification on heavy metal contents in soils and vegetation of semi-natural ecosystems at Rothamsted Experimental Station, UK. - Plant and Soil 240(2): 235-251.

[2] Celishernandez, O., Rosaleshoz, L., Cundy, A. B., et al. (2017): Sedimentary heavy metal(loid) contamination in the Veracruz shelf, Gulf of Mexico: A baseline survey from a rapidly developing tropical coast. - Marine Pollution Bulletin 119(2): 204-213.

[3] Chen, B. B., Hu, R. Q., Chen, M. D. (1985): Natural background values of environmental elements in coastal soil in Jiangsu. - Journal of Nanjing Agricultural University 8(3): 5460 .

[4] Dobaradaran, S., Soleimani, F., Nabipour, I., et al. (2018): Heavy metal levels of ballast waters in commercial ships entering Bushehr port along the Persian Gulf. - Marine Pollution Bulletin 126: 74-76.

[5] Guan, Q., Wang, L., Pan, B., et al. (2016): Distribution features and controls of heavy metals in surface sediments from the riverbed of the Ningxia-Inner Mongolian reaches, Yellow River, China. - Chemosphere 144: 29-42.

[6] Hakanson, L. (1980): An ecological risk index for aquatic pollution control. A sedimentological approach. - Water Research 14(8): 975-1001. 
[7] Harikrishnan, N., Ravisankar, R., Chandrasekaran, A., et al., (2017): Assessment of heavy metal contamination in marine sediments of East Coast of Tamil Nadu affected by different pollution sources. - Marine Pollution Bulletin 121: 418-424.

[8] Hyun, S., Lee, C., Lee, T., et al. (2007): Anthropogenic contributions to heavy metal distributions in the surface sediments of Masan Bay, Korea. - Marine Pollution Bulletin 54(7): 1059-1068.

[9] Jahan, S., Strezov, V. (2018): Comparison of pollution indices for the assessment of heavy metals in the sediments of seaports of NSW, Australia. - Marine Pollution Bulletin 128: 295-306.

[10] Keshavarzi, B., Hassanaghaei, M., Moore, F., et al. (2018): Heavy metal contamination and health risk assessment in three commercial fish species in the Persian Gulf. - Marine Pollution Bulletin 129(1): 245-252.

[11] Li, C., Song, C., Yin, Y., et al. (2015): Spatial distribution and risk assessment of heavy metals in sediments of Shuangtaizi estuary, China. - Marine Pollution Bulletin 98(1): 358-364.

[12] Li, F., Xu, M. (2014): Source Characteristics and Contamination Evaluation of Heavy Metals in the Surface Sediments of Haizhou Bay. - Environmental Science 35(3): 10351040.

[13] Liang, X., Song, J., Duan, L., et al. (2018): Source identification and risk assessment based on fractionation of heavy metals in surface sediments of Jiaozhou Bay, China. Marine Pollution Bulletin 128: 548-556.

[14] Liu, F. C., Zhang, C. Y., Peng, J. (2010): Characteristics of spatial variability of sediment grain size in the Haizhou Bay. - Marine Sciences 34(7): 54-58.

[15] Lu, X. Q., Werner, I., Young, T. M., et al. (2005): Geochemistry and bioavailability of metals in sediments from northern San Francisco Bay. - Environment International 31(4): 593-602.

[16] Lv, J., Liu, Y., Zhang, Z., et al. (2015): Identifying the origins and spatial distributions of heavy metals in soils of Ju county (Eastern China) using multivariate and geostatistical approach. - Journal of Soils and Sediments 15(1): 163-178.

[17] Müller, G. (1969): Index of geoaccumulation in sediments of the Rhine River. Geojournal 2(3): 108-118.

[18] Nguyen, T. T, H., Zhang, W., Li, Z., et al. (2016): Assessment of heavy metal pollution in Red River surface sediments, Vietnam. - Marine Pollution Bulletin 113(1-2): 513.

[19] Naifar, I., Pereira, F., Zmemla, R., et al. (2018): Spatial distribution and contamination assessment of heavy metals in marine sediments of the southern coast of Sfax, Gabes Gulf, Tunisia. - Marine Pollution Bulletin 131: 53-62.

[20] Pejman, A., Bidhendi, G. N., Ardestani, M., et al. (2017): Fractionation of heavy metals in sediments and assessment of their availability risk: A case study in the northwestern of Persian Gulf. - Marine Pollution Bulletin 114(2): 881-887.

[21] Phillips, D. P., Human, L. R., Adams, J. B., et al. (2015): Wetland plants as indicators of heavy metal contamination. - Marine Pollution Bulletin 92(1): 227-232.

[22] Qiao, Y., Yang, Y., Gu, J., et al. (2013): Distribution and geochemical speciation of heavy metals in sediments from coastal area suffered rapid urbanization, a case study of Shantou Bay, China. - Marine Pollution Bulletin 68(1): 140-146.

[23] Qu, B., Song, J., Yuan, H., et al. (2018): Intensive anthropogenic activities had affected Daya Bay in South China Sea since the 1980s: evidence from heavy metal contaminations. - Marine Pollution Bulletin 135: 318-331.

[24] Rahman, M. A., Ishiga, H. (2012): Trace metal concentrations in tidal flat coastal sediments, Yamaguchi Prefecture, southwest Japan. - Environmental Monitoring and Assessment 184(9): 5755-5771.

[25] Reddy, B. C., Jayaraju, N., Sreenivasulu, G., et al. (2016): Heavy metal pollution monitoring with foraminifera in the estuaries of Nellore coast, East coast of India. Marine Pollution Bulletin 113(1): 542-551. 
[26] Singh, K. P., Mohan, D., Singh, V. K., et al. (2005): Studies on distribution and fractionation of heavy metals in Gomti River sediments - a tributary of the Ganges, India. - Journal of Hydrology 312(1): 14-27.

[27] Tomlinson, D. L., Wilson, J. G., Harris, C. R., Jeffery, D. W. (1980): Problems in the assessment of heavy-metal levels in estuaries and the formation of a pollution index. Helgoländer Meeresuntersuchungen 33: 566-575.

[28] Wang, M., Tong, Y., Chen, C., et al. (2018): Ecological risk assessment to marine organisms induced by heavy metals in China's coastal waters. - Marine Pollution Bulletin 126: 349-356.

[29] Wang, Y. S., Lou, Z. P., Sun, C. C., Sun, S. (2008): Ecological environment changes in Daya Bay, China, from1982 to 2004. - Marine Pollution Bulletin 56: 1871-1879.

[30] Wilcke, W., Muller, S., Kanchanakool, N., et al. (1998): Urban soil contamination in Bangkok: heavy metal and aluminium partitioning in topsoils. - Geoderma 86(3): 211228.

[31] Zhang, C. Y., Feng, X. L. (2009): The spatial distribution and analysis about the grainsize of sediments in the Lianyungang nearshore sea area. - Acta Oceanologica Sinica 31(4): 120-127.

[32] Zhang, P., Hu, R., Zhu, L., et al. (2017): Distributions and contamination assessment of heavy metals in the surface sediments of western Laizhou Bay: implications for the sources and influencing factors. - Marine Pollution Bulletin 119(1): 429-438.

[33] Zhang, R., Zhou, L., Zhang, F., et al. (2013): Heavy metal pollution and assessment in the tidal flat sediments of Haizhou Bay, China. - Marine Pollution Bulletin 74(1): 403-412.

[34] Zhao, Y. F., Xu, M., Liu, Q., et al. (2018): Study of heavy metal pollution, ecological risk and source apportionment in the surface water and sediments of the Jiangsu coastal region, China: a case study of the Sheyang Estuary. - Marine Pollution Bulletin 137: 601609.

[35] Zhu, Z. M., Li, Z. G., Bi, X. Y., Han, Z. X., Yu, G. H. (2013): Response of magnetic properties to heavy metal pollution in dust from three industrial cities in China. Hazardous Materials 246-247: 189-198. 